\title{
Introduction to the Gothic Handbook Series: Welcome to Hell
}

\author{
Clive Bloom
}

In 2019, London was host to an immersive zombie exhibition at the Truman Brewery, Brick Lane in East London attached to the television show The Walking Dead, a new play about Dracula was staged at the London Library and an art installation, sponsored by the Ben Oakley Gallery and called 'Monster' by Giles Walker, featuring headless clowns and other freakery, was set to be held in an empty warehouse near Greenwich later in the year if sufficient crowd funds could be raised. Exotic drinks and fried insects may be consumed at tables inlaid with skeletons at the Victor Wynd Museum and cocktail bar in Hackney and elsewhere in East London the enthusiast may visit the Jack the Ripper Museum in Cable Street or eat at the Serial Killer Café in Brick Lane, or even shop at a Romanian convenience store called 'Dracula' in the suburbs. In front of the prestigious Royal Academy, Cornelia Parker exhibited a scale model of the Bates Motel (called 'PsychoBarn'), whilst The Woman in Black, Stephen Mallatratt's adaptation of Susan Hill's novel has been playing since 1987 and has been in the West End since 1989, the second longest running non-musical after Agatha's Christie's The Mousetrap. George A. Romero's Night of the Living Dead was yet another example of immersive theatre, playing during May of 2019. Last and most significant of all, is the Grand Guignol of The London Dungeon, a horror experience originally devised as a 'wax museum' now a horror venue currently with nineteen shows, twenty actors and two thrill rides. One may multiply examples from around the world, but in London alone the gothic experience seems alive and thriving. ${ }^{1}$ With the appearance of Covid-19 in 2020, London became, for a moment, an empty space: a dead city of a gothic apocalypse.

Every new medium, from film to television to the Internet and social media, has remoulded gothic tropes for a new generation. At the same time older gothic tropes are constantly revisited and reworked in new contexts. The gothic sensibility saw the rise of science fiction through Mary Shelley, detective fiction through Edgar Allan Poe and dark romance through the likes of the Bronte sisters. Vampires, wolfmen and zombies fill our screens, video gaming platforms and social media.

C. Bloom $(\triangle)$

London, UK 
Frankenstein's monster make-up, as created by Frank Pierce for James Whale's film of the same name is perhaps the most important gothic image of the last century, influencing everything from films to toys, to Halloween costumes; and then there is Dracula (1897). Bram Stoker's tale has not only become the most influential Irish novel, but its protagonist is one of the most popular fictional characters, influencing literature and culture in ways thought most unlikely when the book made its first appearance. Such monsters are the nightmares of modernity.

It is a genre that may be deeply serious or simply entertainment of a most visceral kind. Moreover, the very nature of its often popular and pulp appeal is the fact that the very seriousness it avoids allows for serious issues to emerge as a latent set of subtexts, not necessarily fully understood by its author(s), nowhere more obviously than in the work of H. P. Lovecraft who now has a commanding place in gothic and steampunk culture with numerous novelistic homages to the Cthulhu mythos, as well as in pulp video games, artworks and tabletop gaming. Above all, the Gothic is both high culture and a low culture experience of mere pleasure (often at the same moment), destroying barriers of taste and refinement to allow for intellectual debate which incorporates both. Nowhere is this more obvious that in the packed lecture theatres of prestigious universities where the Gothic has become as important in literary, cultural, media, film, feminist and sociological studies as more traditional subjects.

Despite the fact that gothic entertainment had flourished in both literature and film from the start of the century to the early 1940s, a taste for atomic, alien and radiation monsters almost extinguished the genre. Now audiences had to 'watch the skies' (the last line from Christian Nyby's 1951 science fiction film, The Thing from another Planet) rather than watch their backs and horrors from outer space replaced terrestrial monsters. Horror and gothic filmmaking were out of favour, but films such as Alberto Cavalcanti's Dead of Night (1947), with its iconic ventriloquist's dummy, kept interest alive. The 1950s were also a lean time for gothic fans although later in the decade the taste revived, heralded by the new Hammer horrors and by Jacques Tourneur's Night of the Demon (1957) based upon M. R. James's Casting the Runes and rather sillier stuff such as the comedy thriller, The Bat (1959) directed by Crane Wilbur who adapted the story from a book from 1908. The Bat ran as a double bill in the United Kingdom with Terence Fisher's The Mummy (1959). By the late 1950s, Hammer Films had reinvented the gothic horror genre, going back to the Universal film classics and remaking them as Victorian melodramas, and in so doing recreated Dracula and Frankenstein for the 'modern' age. The Curse of Frankenstein (1957) was followed by Dracula (1958) and The Mummy (1959). The new terrors were themselves only able to exist because of the success of Hammer Horror's profitable adaptations of the science fiction television series The Quatermass Xperiment (1953). The series was first reworked as The Quatermass Xperiment (1955) directed by Val Guest and capitalised on the new $\mathrm{X}$ rate horror category. The Hammer horrors followed. Technicolour blood and gore, overt sexuality and psychopathic violence were key features of films whose modernity was a peculiar form of nostalgia for an attenuated Victorianism. 
Nevertheless, a 'debased' and often plagiaristic form of the genre was also invented for children during the 1950s. The appearance of the subculture of gothic comics such as Weird Science, Tales from the Crypt and The Haunt of Fear brought writers such as Edgar Allan Poe and H. P. Lovecraft to the attention of younger readers (through highly plagiarised rewriting) who then were free to source the original stories. Despite the horror comic scare and legislation brought in by the British government in 1955 (partially initiated by the Gorbals Necropolis 'vampire' scare), gothic tales were back for a new generation.

Meanwhile Roger Corman went back to Edgar Allan Poe to produce a series of films whose gothic look influenced (quite unconsciously perhaps) the gothic fashion of the late 1980s. His colour-coded use of mise en scene and strange hallucinatory dream sequences remain part of a psychedelic age. In the 1970s the production company Amicus went back to Weird Tales for its anthologies of shudders, often borrowing Hammer stars like Peter Cushing or Christopher Lee to play in their portfolio stories. Occasionally they even borrowed directors too. As Corman created sensuous landscapes so William Castle created three dimensional gimmicks that have been reinterpreted in even more gothic terms and, of course, in the 1960s with the television reruns of the Universal series and renewed interest in Charles Addams, the supernatural and Gothic became central to children's television with series like The Munsters (1964-1966), The Addams Family (1964-1966) and Scooby Doo (original series, 1969), not to mention Bewitched (1964-1972) and I Dream of Genie (1965-1970), all being must-see programmes after school. Whilst for many years The Simpsons have produced amusing Halloween specials.

Before the growth of academic studies of the Gothic there were dedicated bibliophiles such as Montague Summers, collectors such as Michael Sadlier and enthusiasts such as August Derleth, whose cause was the author they loved or the rare volumes that they catalogued. The extraordinary growth of both the gothic industry and gothic studies is largely due to a combination and coincidence of factors. The academic study of gothic books had at least to wait until the revival of the weird, ghostly and horrific in the late 1960s and early 1970s when Pan, Panther and Corgi as well as other paperback imprints revived the likes of Arthur Machen, R. E. Howard and H. P. Lovecraft (without whom we would not have a gothic Batman whose nemesis lives in Arkham Asylum!). This led to the revival of writers like Denis Wheatley whose The Devil Rides Out (1934; film 1968) To the Devil a Daughter (1953; film 1976) and The Haunting of Toby Jugg (1948; film 2006) made both a literary and filmic comeback. Wheatley's lifelong interest in Satanism, the occult and black magic were later published in his non-fiction account The Devil and All His Works (1971), a book that influenced a generation of younger readers.

Ghost hunters such as Harry Price and his investigations at Borley Rectory in the 1940s were rediscovered in the 1960s and 1970s, his books reprinted and his life reassessed in books such as Paul Tabori's Harry Price: Ghost-Hunter (1974) published by Little Brown in the Denis Wheatley Library of the Occult. The incredible rise in the fortunes of the occultist Aleister Crowley were such that he ended up, alongside Edgar Allan Poe, on the cover of the Beatles 'Sergeant 
Peppers Lonely Hearts Club Band' (1968), not least because Wheatley referenced him in The Devil Rides Out and other novels. Crowley's own books were reprinted and his ideas widely circulated, whilst novels such as Moonchild (1917) and Diary of a Drug Fiend (1922) were reprinted in American paperbacks in 1970 and 1972. Cheap and lurid paperback covers lured teenagers and young adults to Edgar Allan Poe whilst an older counter culture embraced Poe, Crowley and Tolkien.

Because of YouTube it is possible to watch the melodramas of Tod Slaughter or the delights of the films of Val Lewton and fit them into the 'lost' history of British or American gothic film and popular entertainment. In the case of Tod Slaughter, a world of forgotten working-class melodramatic entertainment and values is again revealed (his version of Sweeney Todd was played by his company 'The Barnstormers' at the Independent Theatre Club, in Great Queen Street, London). In the same way it is possible to watch an Alexander Mc Queen gothic catwalk show or gothic animation. Gothic imagery flourishes in the new social media. Music videos are readily available on numerous platforms and such platforms allow for new gothic culture to emerge in the animations such as Lenore the Cute Little Dead Girl or the vlogs of entertainers and lifestyle gurus such as Aurelio Voltaire (The Lair of Voltaire) or the impassioned arguments of amateur horror film critics or television aficionados. The possibility of gothic renewal and of nostalgic revisiting now seem endless. Indeed, the very definition of the Gothic as the expression of an atmosphere filled with anticipation or dread cannot, any longer, properly be applied to gothic lifestyle, fashion or music as it might have been only a few years ago.

The term Gothic may have become broad and inclusive, but it must still retain its original features in order to be recognised even if the recognition proves false. Gothic clothing developed in the post punk atmosphere of do it yourself make and mend, defiantly defining its black clothing, tatty lace, jet black hair, white pancake make-up and kohl against mainstream fashion. It was a fashion of exclusion and alienation in keeping with the nihilism and economic depression of the late 1970s and early eighties rather than emulating the aesthetic nihilism of the late nineteenth century. The appropriation of gothic tropes for high fashion labels with its 'heroin' thin models and edgy horror subject matter intended to épater le bourgeoisie was itself a form of aggrandisement into the world of youth culture.

Horror, now always associated with the idea of the Gothic, on the other hand is a visceral consequence of anticipation and in that sense may or may not be Gothic at all. It is perfectly possible to have a gothic film which is without horror (Rebecca [1940]; Dragonwyck [1946]) and it is possible to have a horror film that has nothing of the Gothic (28 Days Later [2002]; Witchfinder General [1968]; The Wicker Man [1973]), yet gothic horror as a term has existed long enough to make clear distinctions difficult and pedantic. Edgar Allan Poe's gothic storytelling always leads to a horrific revelatory denouement and as such may claim to be the first set of tales that may be explicitly designated gothic horror. It is clear that definitions created by the original eighteenth-century writers have to be heavily qualified, stretched to breaking or abandoned in the face of the modern zombie which have no real origins beyond the 1930s and whose 
reinvention is a result George A. Romero's Night of the Living Dead (1968), a visualisation of events during the Civil Rights movement. Study of gothic culture is therefore both dynamic and chronological and has to take into account cross influences from diverse areas and be alive to the possibilities of homage, pastiche and irony.

The adolescent reading of future academics became a source of serious enquiry in the 1980s when horror and gothic pulp authors were revisited by post-modernist scholars and when psychological (especially Freudian ideas of uncanniness) and sociological readings (especially Marxist and post-modern readings of popular culture and literature) were in the ascendant. The writers of horror were the 'other' of F. R. Leavis's canonical authors and a breath of fresh air in a restricted academy. This alternative canon was then opened to cultural studies, psychoanalytic readings and research from feminist and later ethnic researchers. Gothic writers whose work had faded or been forgotten, now returned in new scholarly editions ready for dissection and there was a vogue for compilations of essays on the gothic and introductions to what was a fledgling subject, whilst Edgar Allan Poe was given the full attention of French post-modern theory in the journal Yale French Studies. The gothic tales of forgotten authors were republished and their place in literary history rethought; the silent gaps were finally being filled. In this way Ann Radcliffe and the writings of long-forgotten women gothic novelists were put back into the purview of academic research. New terms were mobilised: the uncanny, abjection, liminality, to be replaced by further theorising in the world of disability, gender stereotyping and ecological studies.

Yet study could not really begin until the appearance of both published reprints of classic or lost works and the reruns of Universal films on television. This led inevitably to nostalgic pastiches such as Mel Brook's and Gene Wilder's Young Frankenstein (1974) (an almost Yiddish pastiche with undertones of Marx Brothers slapstick and verbal wit) and Richard O'Brien's Rocky Horror Show (play 1973; film 1975), a mash-up of science fiction and gothic film elements mixed with a dose of gender confusion and glorious cross-dressing. The real turning point may be considered the appearance of video and Betamax, followed by the appearance of the televisual pause button, and the creation of YouTube uploads and other reproductive media which allowed multiple viewing. DVDs came with sub titles and commentary, and deleted scenes which could be evaluated and discussed by academics and enthusiasts alike. The rediscovery of Carl Dreyer's Vampyr (1931) and the ability to re-run Hammer films allows for a serious re-evaluation of Jimmy Sangster's scriptwriting, Terence Fisher's directing and James Bernard's music and what makes their work 'classic'. Video and disc technology is central to the re-evaluation of films like Dario Argento's Suspiria (1977) and Don Coscarelli's Phantasm (1979) and reworking their themes would be difficult without this technology. Even the return of Ed Wood's campy low budget films has much to do with new technology. Goth culture needed multiple stimuli that could be revisited and analysed. That having happened, real debate could take place and facts and concepts checked especially with regards to ephemeral or peripheral material. 
We live now in an age of international gothic where the genre has crossed borders, as much alive in Brazil as London or New York and where discussion of zombies and vampires is both an intellectual holiday and a serious focus of attention. Nowadays there is no single overarching definition we can bring to bear on a culture that encompasses literature and club culture, television and fashion, video games and urban studies. The fruit of all these years of focus has been the creation of an academic gothic community and a huge range and diversity of opinion. Yet the Gothic is always meant to entertaining as well as intellectually stimulating.

The Gothic as cultural phenomenon has now travelled beyond a limited selection of books or films. This makes it a very dynamic field with new books and new discoveries stimulating further discussion. Such discussion will inevitably change older definitions and invalidate previous boundaries, creating new areas of interest, informed by, but no longer held back by, older theories. The recent translation of an alternative version of Dracula 'written' by the Icelandic author Valdimar Assmundson and published in Iceland in 1901 under the title Markt Markanna or Powers of Darkness is an example of a 'lost' work providing new areas of discussion. This version, first fully translated into English by Hans Corneel de Roos and published with extensive notes, presents a quite new version of the Dracula tale, apparently, although contentiously, authorised by Bram Stoker himself and indeed, there is much discussion and controversy still regarding the origins of the Swedish and Icelandic versions. In architecture, the restoration of both the Houses of Parliament and Strawberry Hill suggests there will be more to be done in terms of research into neo-gothic buildings as well.

How might we define gothic culture, gothic art and gothic taste? On the one hand the Gothic is a sensibility, on the other the effect of having such sentiments. In this equation there is a moment in history when sentiment and cultural expression became one expression of cultural identity. In this equation there is no before and after, but a synchronicity that has gothic effects produced through a gothic way of thought, emotion and expression. Of course the Gothic may be defined by a particular era, as once it was in literary histories of popular reading. We can mark the period exactly from 1764 to 1820 or from Horace Walpole's The Castle of Otranto to Charles Maturin's Melmoth the Wanderer. Thus a beginning and an end, of sorts, is constructed. Nevertheless, it is clear that different gothics and different gothic sentiments pervade the neo-gothic arts dated around the Romantic and post-French Revolutionary period, which are connected to, but different from those feelings and sentiments that fill gothic melodramas in the mid-nineteenth century or which inform gothic fin de siècle dalliance with the occult.

Thus, there is a puzzle at the heart of gothic literature. Not only does it develop in a diametrically opposed way to gothic architecture and design, which stands for the most part for the revived medieval and Tudor, imperial aspirations and high Christian virtues, but it does so within that framework as its inherent opposite. Hence it may be argued that gothic literature and culture are both misnamed, through historical accident or is gothic literature the subversively repressed of the virtues listed as the features of the architectural revival?

If the gothic's origins are to be found in historical circumstance and artefacts, they are also a reminder that the sentiments expressed in such artefacts held within 
them a fascination of a quite different sort. If that is accepted then there must be two gothics, one wholesome and the other unwholesome, one pure and one corrupt, expressing themselves as doppelganger mirror images. Thus the Gothic is both an epistemological conundrum and a history of artistic expression with a chronology that may be followed. It is, perhaps, either and both and this being so the circle cannot yet be closed, either on its historical trajectory or its meaning until the period of its formation and development finally fade into dead history.

For the contributors to this volume such problems are significant. ${ }^{2}$ Giles Whiteley defines the genre with elegant simplicity, for him, the Gothic is a form of macabre writing, either terrific or horrific with supernatural themes and featuring narratives set in the middle ages. Valeria Iglesias-Plester sees 'the main aspects as foreshadowing, the use of labyrinth-like structures' including, 'the haunted' [which may be a house or a person or family], whilst Marta Vega sees space itself and setting as forming the tone of gothic feelings. Marius Crisan suggests the links is between the real and the imaginary, between man and divinity and between life and death. As such the gothic narrative is effectively one of childhood and adolescence, but as Agnieszka Kotwasinska points out it is also a world of decay and dust. Dust and decay are for Eric Parisot 'about the artistic articulation of fear(s) whether personal, social, cultural, political or historical. Some of these fears we may be aware of, but the best gothic art is able to tap into or articulate fears which we are not yet cognisant' and therefore for James Rattue such fears represent 'our repulsion from, and attraction to, the potential undoing of the human'.

Holly-Gale Millette reminds us of the origins and continuance of gothic themes 'such as the sublime, the subliminal, the grotesque, the revenant, the uncanny in the aesthetic, political and social structures of sentient life forms - past, present and future'. Whilst Manuel Aguirre sees the early gothic as originating as 'an aesthetic mode which later crystallized into a historical genre'. For Aguirre, the Gothic postulates a 'second space' beyond the limits of the rationalist enterprise and endlessly negotiates the threshold between the human reality and that of the numinous 'Other' where the terrors of power (and the power of terrors) act unchecked.

We can, of course define the Gothic by its monsters and its relationship with the importance of religion as does Aspasia Stephanou who suggests that, the genre 'is characterised by the presence of supernatural phenomena, including vampires, ghosts, zombies and the occurrence and repetition of the past and the uncanny. The problem is defining the supernatural as that which comes from without and revolves around the idea of a theistic universe'. Looked at philosophically and from an historical viewpoint, Cleo Cameron comments that, 'the gothic suffers from delusional dualism, when in actuality it is defined by radical monist materialism-experiencing the sublime gothic supernatural, the individual's suffering mind, via symbiosis with the nervous system, which tortures and torments the body through its reactive imaginings when exposed to the metaphysical dualism implied by the apparently witnessed supernatural episode'.

In all its forms, Brian Jarvis remarks, the Gothic represents a 'politics of excess' and 'delirium', and Martina Barlett sees this emerging from the collision of ideologies which cannot be reconciled. In this way, encountering the other's 
foreign-ness in all its physicality may trigger the gothic impulse as a reflection of one's own culture as Carol A. Senf believes. As Emma Dallamora argues, 'the gothic is acutely about the unconscious and this argument agrees with Jessica Gildersleeve's, that such repressions are mainly unconscious. Sandra M. Casanova-Vizcaino believes the Gothic moves through the eras, reflecting the fears, the desires, the spaces, and the bodies that reflect the most salient (and perhaps most ingrained) aspects of society's deepest recesses. Nowadays those fears revolve around the body, technology and the non-human'.

Catherine Redford considers that, 'the gothic is characterised by an anxiety about otherness, and particularly a fear that this otherness'. Hence, 'this darkness, speaks to something familiar within us'. The Gothic is a mode of cultural production that pertains to the exploration of otherness and uncanny familiarity, and is therefore focussed on the construction and dissolution of boundaries, the obsession with death, violence and the grotesque. It is often set in claustrophobic spaces, either real or imaginary. One of its most prominent features is its ability to mutate and adapt to different times and spaces, becoming an effective reflection of societal fears.

The Gothic is above all a hybrid mode: it often appears in collaboration with other literary forms, modes and genres. Where fear is disguised so may other subject matter. Paulina Palmer points out that this leads to the possibility of a genre as an 'appropriate vehicle for the representation and analysis of queer sexualities and genders, especially the experiences of secrecy, loneliness, the hidden, liminality, and living on the margins between queer and heterosexual cultures that queer and LGBTI communities often experience' and the number of gothic novelists from marginalised groups certainly bears this out.

Such ideas are widened by Dara Downey who gives this explanation: 'One of the most useful definitions of the gothic is actually a line from The Turn of the Screw (1898) by Henry James who writes that 'an unknown man in a lonely place is a permitted object of fear to a young woman privately bred'. Downey thinks 'that this encapsulates many of the dynamics of class, gender, and knowledge that the genre repeats and rearranges in various ways and thus some of the terms can be moved around or substituted to account for different relations in terms of class, race, gender, and so on'. This being the case Julia Round returns the argument to the world of 'haunting' with its connotations of 'excess and contradiction' revealing 'the hidden meanings of fear and attraction', simultaneously giving us too much information (the supernatural) and also not enough (the spectral and unseen).

Antonio Alcalá González points out that, 'in the gothic [world], human beings find it impossible to escape from the past lurking behind them'. David Ibitson suggests it is genre that allows a 'willingness to look awry, or askew, at society, to reveal what others may want to hide or ignore; to reveal uncertainties about society that have been rendered monstrous by their being ignored...'. '[Or]... it is about the return of social and psychologically repressed neuroses'. Indeed 'in broad terms the Gothic is an undead past that disrupts the present...though such temporal discombobulations can haunt the present from the (possible) future as 
well' suggests Simon Bacon. Thus, Mark Bernard finds racism at the very heart of the (American) gothic project. He argues that, 'the most compelling aspect of the gothic is how it depicts anxieties regarding the way the past will consume our present and preclude our future; in America, this past is haunted by Native American genocide, slavery, and other racial injustices, and American gothic tries to contend with the horrors from the past that infect our present'.

David Jones points out that the 'gothic is a hybrid and hybridising term, used [both] to characterise shifting layers of meaning involving expressions of dark, frightening and repressed urges as well as social, sexual and familial transgression and violence, and the perceived barbarism of wilder (sometimes primitive) styles of creativity'. This leads Marie Mulvey-Roberts to conclude that hybridity is central to the very nature of gothic productions. She considers that, 'the gothic seems to have been a process of moving from the margins to the mainstream and by doing so becoming increasing difficult to define due to its capacity for absorption, hybridity and even appropriation', a point reiterated by Jarlath Killeen who notes that "the term would have to be limited by the meanings circulating in the period, but given the way "Gothic" is promiscuously employed in popular culture now, ... it is important to be as open as possible'. Whilst it may be 'promiscuous', in a real sense, gothic is the literature of the traumatic, whether it be the physicality of the monstrous or the trauma of bodily disintegration or even the return of the dead, gothic caters for morbid fascination and serious critique. In the present century gothic pleasure may encompass music, fashion, lifestyle, social media, art installations and amusement park rides.

Coincident with these conceptual boundaries is the chronology of the Gothic itself. In its chronology is the genesis of gothic ideas, sentiments and tropes, but as might be inferred from its definitions the ideas themselves may belong to a more ahistorical perspective which is greater than the evolution of events. Thus terms such as liminality, abjection or the uncanny may have an interpretive base greater than one or more chronological occurrences. Nevertheless, there is a chronology which we can outline.

The first phase is, course, pre-gothic, lasting from the seventeenth century to the publication of Horace Walpole's The Castle of Otranto, in 1764. The idea of the Gothic (as distinct mode of expression) originates with a reaction to neoclassicism in thought and ideas with a growing emphasis on indigenous non-Roman British history, such as that of the druids, burial mounds and Stonehenge investigated by clerical antiquarians from the seventeenth century onwards. The term 'goth' was adopted in architecture by patrons and architects looking for an 'authentic' Christian medieval (English) vernacular style, a style which finds expression in the work of John Vanbrugh and later in Strawberry Hill. This resulted, both by design and by accident, in an interest in revolutionary, unusual, bizarre and outre concepts in design, for which new words such as 'gloomth' and 'serendipity' were coined (by Walpole) to express the feelings evoked by the architecture.

Gothic literature however emerged from a fascination with death and momento mori as threatening rather than consoling, resulting in Walpole's own nightmare 
induced The Castle of Otranto which combined the natural style of the contemporary novel with the superstitions, supernaturalism and intrigue of an imagined feudal past. Walpole's 'amusing' nightmare regarding his own house joined architectural Gothic to literary Gothic by the merest chance. Shakespearian plotting from Hamlet, Richard III and Macbeth linked eighteenth-century sentiment to medieval imagery and imagined language.

The second phase lasted from the 1780 s to the 1790 s. This is really the height of the gothic revival in literature with over two hundred known examples of the genre produced in English alone. Gothic was expanded to create the theatre of spectacle where there was a split between those who believed gothicism was a metaphor for Godlessness and those who, influenced by De Sade were believers in a Godless universe where only appetite and power succeeded. The contradiction is best described by comparing Ann Radcliffe (whose idea of 'terror' leads to God) or Joanne Baillie whose plays suggest the Gothic is a place of lost composure with Matthew Lewis or Charlotte Dacre (who embrace both horror and perversion). The genre was now seen as either the triumph of virtue over evil (the evil usually being entirely human) or the triumph of Luciferian instincts over rationalism.

In the last decade of the eighteenth century, we also witness the beginnings of German supernaturalism as originated in Gottfried August Burger's poem Lenore (1773), based on British border ballads and then reabsorbed into British literature itself and thereafter rewritten and quoted in other gothic novels such as Dracula. Such German influences suggested the Gothic was more attached to demonic disruption and damnation in a universe bereft of spiritual guidance or the hand of God.

Major themes also began to emerge such as the 'corpse bride' and the necromancer/who first makes an appearance in William Beckford's Arabian tale Vathek (1782 in French and 1786 in English) which itself introduces the other side of the gothic imagination-orientalism.

From 1800 to the 1840s there is the architectural triumph of medievalism as the principle of high Anglicanism and imperialism expressed by the building of the Houses of Parliament and the colonial administration buildings in colonial capitals, the general church building programme and the appearance of new gothic craft wares, silver and furniture, the new garden cemeteries such as Highgate and Kensal Green, the ideology of the 'Young England' movement, the later industrialised architecture of Tower Bridge and novels such as Walter Scott's Ivanhoe (1818). Scott's own Scottish baronial style was reflected in the remodelling of Windsor Castle and Bavarian King Maximillian's building of Hochschwangau in Bavaria. Such reactionary and conservative ideas were the consequence of the threat of the French revolution and the collapse of social hierarchy, but this also led to radical ideologies of the existential self in a non-Christian Godless world exemplified by Mary Shelley's creature in Frankenstein (1818), John Polidori's The Vampyre (1819) and Charles Maturin's fantasy about a Kafka-esque bureaucracy in Melmoth the Wanderer (1820).

The ideological debates around the break-up of a recognised social order include the rise of the concept of an individualised (Romantic) imagination. This 
created a new ontological perspective wherein the individual became the basis for the sense of reality. Personal reality soon became personal realities where heightened imagination was both liberating, but also a solipsistic trap leading to insanity. Those locked in their own heads would now be subject to doubts regarding the validity of the outside world. The major shift from external dangers to internal fears and the idea that the 'architecture' of the mind now became the real landscape of terror, led to the rise of psychologised stories and poems which were concerned with hallucination, perversion, murder and drug addiction. Thomas De Quincey, Robert Browning, Alfred Tennyson and Edgar Allan Poe spent much of their literary careers investigating such strange states of mind.

By the 1840s, the original eighteenth-century sense of the Gothic had now long descended into popular culture. This older external gothic was now confined to popular journalism and cheap fiction serials like James Rymer and Thomas Pest's Varney the Vampyre (1845-1847) or serialised melodramas like Rymer or Thomas Prest's The String of Pearls (1846-1847) which introduced Sweeney Todd. Village magic lantern shows and penny gaffs made up the bulk of common gothic experience. The internal (and more intellectual) gothic and the popular sensational version influenced new genres such as the detective novel and the dark romances of the Bronte sisters. Gothic tropes were now used as ironic decoration or as comic setting by British writers such as Charles Dickens, but had also been taken up in the revolutionary atmosphere of Paris by French artists such as Victor Hugo and Charles Berlioz. By the 1840s, the Gothic has even entered the vocabulary of European revolutionaries such as Max Stirner and Karl Marx, who were fascinated with the resonance of the rhetoric of the spook.

The 1850 s to the 1880 s was the apex of gothic architecture and design. In Bavaria, Ludwig II began building Neuschwanstein as a shrine to Wagnerian values. On the stage and in literature old-style Gothic was eclipsed by middleclass social melodrama set in domestic, if (often) gothic, architectural space. Nevertheless, by the 1870s and 1880s, the Gothic revived with the work of Sheridan Le Fanu and Robert Louis Stevenson. This phase is accompanied by the absorption of the new wave of spiritualism coming from America which will influence the occult novels and short stories of the 1890s.

Between 1890 and 1918, the Gothic as occult literature made a remarkable revival. This was an amazingly productive period where old tropes were revived and rethought. Not only is there a revival of old defunct tropes such as the vampire, contemporary influences started to take on new gothic nuances. Paramount is, of course, Jack the Ripper in 1888 and the rise of violent anarchism in the 1890s. Spiritualism and séances, occult societies and eastern esoteric beliefs thrived and ghost stories dominated the popular magazines and anthologies. The era includes Richard Marsh and Bram Stoker, Oscar Wilde and H. G. Wells, M. R. James and Arthur Machen, Ambrose Bierce and Hanns Ewers, M. P. Shiel, Vernon Lee, Algernon Blackwood and Robert Chambers, and the wonderfully named ghost writer, Oliver Onions.

In the 1920 s and 1930s a remarkable weird literature that embraced magic, esotericism and the erotic came from the pen of Dion Fortune whose influence 
on gothic occult writing has largely been ignored. Roughly between 1890 and the 1930s there occurred the golden age of weird fictions: tales that explored the rent in the veil of reality and the peculiarities which may lurk beyond, taking on occult and phantasmagoric imagery, hinting at bizarre perversities, Darwinian and scientific degeneracy, the peculiarities of modern psychology and spirituality and the ever present opiate paranoia of unseen ethnic conspiracies and apocalyptic horror (as in Lovecraft). Whilst the nineteenth-century version embraces the hidden, occult and the otherness of beyond the grave, the twentieth century has explored the blankness of space and of meaning. Both take on 'non-meaning' or that meaning beyond rational explanation on the margins of consciousness. In contrast and in concrete bricks and mortar, the Gothic had been increasingly industrialised (see Tower Bridge and Liverpool Anglican Cathedral) in ways that see its last full flourish. Oddly, both weird fiction and late gothic architecture embrace the fears and aspirations of a world on the brink of modernity.

Even more importantly, the first moving image reinterpretations of gothic sensibility were now being produced in films such as Thomas Edison's Frankenstein (1910). Numerous other short films were produced in the period up to 1919 referencing vampires, golems and other monsters, now all lost. Nevertheless, despite the crumbling of old film reels, from 1918 to the end of World War II, the dominance of cinema was paramount, with film above all, reinterpreting the nineteenth century's representations in literary and stage Gothic through the use of moving imagery and sound accompaniment. Nowhere is the impact of gothic ideas on modernity stronger than on the birth of surrealism in its relationship to film, where filmic technique was able, for the first time, to show complex patterns of psychological alienation and the distortions of surrounding space, explore the passing of time and of memory, visualise synchronicity, alchemy and psychoanalytic insight. These influences were a revelatory moment for Andre Breton who had just seen Nosferatu (1922) as well as to Luis Bunel and Maya Derren. If Salvador Dali went further back to illustrate Walpole and Dorothea Tanning concentrated on Ann Radcliffe, they still came to their subjects through film.

German Expressionist cinema led the way followed closely by Hollywood. American scripts were mostly, but not always rewritings of earlier plays which themselves reworked older novels or stage productions, thereby reusing themes for a visual medium which were previously seen as defunct. Set in imaginary versions of the past or an imagined Bavarian, Ruritanian or Transylvanian setting, films made the world of gothic imagery come alive. Meanwhile, horror literature embraced science fiction with H. P. Lovecraft, Robert Bloch and August Derleth in pulp fiction, and even 'Marxist' ideas appeared in Guy Endore's novel The Werewolf of Paris (1934). As these chapters show beyond the Cold War and through the twentieth and the twenty-first centuries, the Gothic has continued to evolve and grow from film and literature to television and comics, to music, fashion and lifestyle, interactive games and now to environmental and identity politics.

The Gothic is without doubt the longest lasting popular genre in world literature, continuously reinvented throughout the history of modernity as part of modernity itself. This, perhaps extraordinary statement may be justified by 
reference to its ubiquity in a whole range of media over the last 250 years. If we take gothic literature to have been first created in the middle of the Enlightenment by Horace Walpole, then we can map its various organic changes up to and beyond the twenty-first century. The gothic sensibility, which grew as a counter to the philosophy of the period soon adapted itself to the politics of the French Revolution and the new psychological sciences of the nineteenth century. It helped form movements from the picturesque to Romanticism and post-Romanticism, and moved through the nineteenth century picking up concepts of personal disturbance, occultism and domestic violence. By the twentieth century it was immediately adopted by film whose visual vocabulary was found perfect for exploring disturbed states of mind, hallucination, trauma and the spectral.

The term Gothic is a contradiction: on the one hand, it means a Christian, progressive architecture based on medieval principles, whilst on the other, this same architecture is the setting for suspense, supernaturalism, danger, derangement and horror. The Gothic provides a space to discuss issues otherwise banned or censored or so dangerous to societal norms as to appear revolutionary. It exists to allow cultural prohibitions to be disguised as art in order to create a space to explore themes as diverse as physical and mental alienation, borderline states of being, spirits, ghosts and demons and necromancy, incest, fetishism and necrophilia, drug-induced and hallucinatory disturbance, gender construction, sexuality and perversion, predatory violence, the dangers of the urban landscape and its anonymous crowds (think, for instance, of the importance of Jack the Ripper in German Expressionist films such as Paul Leni's Waxworks (1924) and G. W. Pabst's Pandora's Box (1929), or the many Ripper films made in the 1960s and 1970s, and even critiques of class, monstrosity, disability and trauma, which may all jostle in disguised form as literary entertainment.

German Expressionism, with its distortions of visual imagery, was well suited to represent the political, psychological and cultural trauma of the First World War. Horror and psychological disturbance, plague and monsters fill Expressionist Cinema from Robert Wiene's The Cabinet of Dr Caligari (1919/1920) to F. W. Murnau's Nosferatu, and from Carl Boese and Paul Wegener's The Golem (1920) to Paul Leni's The Man Who Laughs (1928) and beyond into Fritz Lang's Metropolis (1927) with its scenes with the scientist Rotwang and the Cathedral clock's skeleton. German Expressionism converted literature into visual images. Although there had been plenty of nineteenth-century images of the Gothic in both print, lantern shows and theatre, it was the success of the German expressionists to find an exact analogue of gothic tropes in the visualisation of distortion, shadows, lighting and set design.

German films incorporated a new filmic sense of the Gothic which was only partially aligned to its literary forbears. Silence and dread were soon incorporated into Hollywood's vocabulary. Tod Browning's The Phantom of the Opera (1925; 1929) and James Whales' Frankenstein (1931) both are cognisant of the influence of German visual tropes as is Alfred Hitchcock, then working in Britain and whose film version of Mrs. Henry Lowndes' The Lodger (book c.1914; film 1927) incorporates an expressionist palette as does his later Blackmail (1929) with 
its vertiginous walk up to the villain's rooms. Such visual tropes went into the very language of film with tropes from The Cabinet of Dr Caligari reprised in Merian C. Copper and Ernest B. Schoedsack's King Kong (1933) and Tim Burton's Edward Scissorhands (1990), Hitchcock's entrance scene in The Lodger (1927) being revisited for Peter Blatty's film of The Exorcist (1973). It is Germanic renaissance medievalism as originally conceived in the middle to late nineteenth century that had its most lasting effect on the work of Walt Disney whose own interest in gothic folk tales and the Brothers Grimm is everywhere evident in his early works such as The Three Little Pigs (1932) and Snow White (1938) with its forest referencing the Klingsor's Garden decorations in the Singer's Hall in Ludwig's II grandiose hermitage, Neuschwanstein which influences the Disney logo and theme parks to this day. Thus twentieth- and twenty-first-century gothic filmic images now vie with, and often are more important than, linguistic tropes to provide another layer for gothic semiotics.

The importance of Hollywood even after the absorption of the German Expressionist film style as well as the emergence of American horror actors such as Lon Chaney and Vincent Price and directors such as Tod Browning, William Castle, Roger Corman, Wes Craven, Tobe Hooper, Eli Roth and numerous others meant that American Gothic looked inward. The phasing out of British directors and European actors in the 1940s meant that the United States could both absorb and replace European Gothic tropes with homegrown ideas. European Gothic slowly became peripheral to the modern American vampire for instance. In 1976, Ann Rice created the Vampire Lestat in Interview with the Vampire, its central characters finally destroying Dracula and European gothicism in an extraordinary act of cultural appropriation.

The slick young vampire kid of the small town schoolyard whose qualms about drinking blood sit alongside his immense wealth fit an American modernity far removed from the old-dark-house school of American Victorian horror which grew out of Edgar Allan Poe, Nathaniel Hawthorne, Ambrose Bierce and the early twentieth-century pages of Weird Tales. What replaced the evil of vampirism was Satanism, covens and black magic conspiracies which were ushered in by Ira Levin in Rosemary's Baby (1968), Peter Blatty in The Exorcist (1971) and by Richard Donner in The Omen (1976). These were themselves pre-dated by Guy Endore's American-in-Paris wolfman horror, The Werewolf of Paris in which a werewolf tale is intertwined with the siege of Paris and the politics of the Communards. The book's peculiarly interest in violence, blood and sexual perversity was based on the equally perverse and decadent writings of Hanns Ewers. Nowhere is the occult and Satanic more revisited than in David Lynch whose visual terrors seem to be attached to a demonic parallel universe residing in subterranean 'lounges' and corridors decorated in the plush red décor of a 1950s cinema.

Demonic characters haunt every episode of Twin Peaks (1990-1991) and Twin Peaks: The Return (2017). We are presented, in episode eight, of the second series which aired in 2018, with the most gothic and surrealist episode in modern television. Lynch's tours de force of occult weirdness, however are often so convoluted and overlaid as to be 'meaningless', instead resonating as a purely visual and 
hallucinatory or dreamlike experience with a confusion of shapeshifting, demonic possession, Lurch-like characters such as the 'Giant'/'Fireman', portals to hellish 'waiting rooms in Limbo, parasitic doubles, demons' ('Bob'; 'Judy'; 'the Arm') and warped or distorted timelines, making the very ordinariness of American small-town life, with its 'cherry pie' and 'damned fine coffee' seem sinister and superficial, hiding the real hell beneath the surface. All of this is composed, at least in the original series, as a soap opera pastiche, a subject he has originally experimented with in his very black 'situation comedy' Rabbits (2002). As agent Dale Cooper reminds his colleagues in Twin Peaks: The Return, 'we live inside a dream' in which the Manichean forces of good and evil eternally battle for supremacy. Here, however, fear is produced from the duality of the known and unknown where evil cannot be explained or fully consciously understood. The images of Twin Peaks produce an America made into a demonic landscape, both uncanny and normal, because nebulous and indefinite, a horror of the inexplicable and irrevocably seen, of that which should not exist under the surface of that which does-American diners, 1950s and 1960s pop music, formica tabletops, wholesome American food and small-town neighbourhood communities.

American Gothic created its own vocabulary in the nineteenth and early twentieth century from its national characteristics and homegrown fears. Thus American Gothic is full of cursed or 'haunted' mansions (both in the eastern seaboard as well as southern states), lonely roads, dense forests, tumbledown shacks and degenerate bayous and swamps. The United States has created its own unique regional concept of the perverse in the southern gothic quagmires of Tennessee Williams and William Faulkner. H. P. Lovecraft created a whole mythic geography of New England degeneracy around Arkham, Miskatonic University, Red Hook and the dreaded 'Necronomicon'. Grant Wood's painting 'American Gothic' (1930) added another level of rural degeneracy, at first unrelated, except by coincidence, to the language of American gothic imagery, as did Hopper's painting 'House By the Railroad' (1925). Hopper's house, with its strange haunting solitude became The Bates Motel and later the home of the Munsters (still later the film set featured in the series Desperate Housewives!) whilst Wood's iconography became part of the opening sequence of the movie version of The Rocky Horror Show in which Riff Raff and Magenta recreate in tableau the famous pose of the farmer and his wife. The contemporary American monstrous must incorporate such areas as consumerism, physical beauty and wealth (see for instance Brett Easton Ellis, American Psycho [1991]), must in a word, be an American businessman's success story. As such the monstrous, per se, is denuded of horror or threat and instead becomes a metaphor for victimhood and exclusion. Victimhood is a focus of early films such as Browning's Freaks (1932) and Whales' The Bride of Frankenstein (1935).

Hollywood land has its own inherent Gothic, the Gothic of faded Spanish architecture, best described in James Cain's Double Indemnity (1943) the noir thriller where the trope may have been invented. This idea of the grotesque combined with a nostalgia for a lost golden age of West coast celebrity is reworked in Billy Wilder's Sunset Boulevard (1950) as well as Robert Aldrich's Whatever Happened to Baby Jane (1962). Norma Desmond in Sunset Boulevard, played by 
Gloria Swanson and Baby Jane, played by Bette Davis both attempt to return from their own version of a living death, being forgotten by an unforgiving film industry. Their final return surrounded by the corpses of those they loved, provides a fittingly macabre trope for the harsh nature of celebrity culture and faded talent from an age that has already past and should not return. It is, in these films a fate meted out to women who cling to the rags of lost glory like the living revenant Miss. Haversham in Charles Dicken's Great Expectations (1861). Such sentiments also pervade the work of David Lynch with the reprised Spanish Hollywood Gothic of Mulholland Drive (2001) in which a central character, Betty played by Naomi Watts dreams of being famous, finally to be destroyed by the demonic forces of failure.

Nowhere is Hollywood homage more obvious than in the work of Tim Burton whose sense of the genre is that of a slightly rye and knowingly arch affection, usually deployed as a reverential, knowing and comic mise en scene rather than that of originality of setting and purpose. His frequent return to rethinkings of classic early Gothic such as in Vincent (1982), Frankenweenie (1984), The Nightmare Before Christmas (1993), Corpse Bride (2005) and Sleepy Hollow (1999) are marked by heightened colour, grotesque make-up and musical numbers, and, like Edward Scissorhands (1990) are often wilfully sentimental. All are marked by a reverence for silent movie gesture and narrative (Edward Scissorhands is a 1990s reworking of Cesare in The Cabinet of Dr Caligari) or they hark back to a nostalgia for lost actors of a type of B-movie golden age such as Vincent Price. Where Burton is of account is in his scrupulous rendition of gothic detail and his almost overwrought and caricatured manner of working with both drawings and puppets. Through multiple gothic incarnations he has effectively turned Helen Bonham Carter into the most recognisable 'gothic female' in modern film. It is in his re-rendering of Stephen Sondheim's Sweeney Todd (theatrical musical 1979; film 2007) that he accomplishes both reverence and innovation. With Sondheim's permission, the choral numbers were rewritten and the story narrated as a nightmare vision of urban depravity and revenge in which everyone goes to the hell that Sweeney's revenge finally brings. There is no happy ending, only a final blackout laced with fountains of blood, the dwellers of Victorian London being reduced to cannibals eating the flesh of Mrs. Lovett's meat grinder. In thus referencing James Whale (in Sweeney's make-up) Burton creates an expressionistic landscape both claustrophobic, isolated and inexorable; rainfall is tainted into urban corruption and turning into blood as it falls. Jonny Depp, eaten up with bitterness, is not Tod Slaughter with his noted melodramatic comic laughter and his sly catch phrase 'can I polish you off, sir?', rather here is a type of urban malevolence without hope or pity based on the ghost of Jack the Ripper, a quite different, but equally charismatic bloodthirsty monster.

There is always change and mutation according to cultural shifts. America itself is the new gothic landscape. Tobe Hooper, Wes Craven and Rob Zombie have turned the backroads and backwoods of the country into killing grounds where innocent (and usually very good looking) college students head off on vacation, run out of fuel, go seek help at apparently empty shacks or collapsing wooden 
mansions and are killed off one by one by masked, deformed and otherwise monstrous degenerates who wield power saws, machetes and hammers in order to torture and mutilate their victims. The old dark house was given a new twist in the 1970s when it turned into the haunted and empty small town house where unspeakable murders have been committed, but whose price does not deter a happy nuclear family moving in only to be traumatised by a past that cannot be exorcised (see, for instance Jay Anson's 'factual' retelling of The Amityville Horror [1977] or Stephen Spielberg and Tobe Hooper's Poltergeist [1982]). The shift in FBI strategy in the 1970s from looking for communists to searching for serial killers also changed the focus of American horror and gave urban and campus landscapes a gothicism hitherto ignored, with movies like John Carpenter's Halloween (1988) and Sean S. Cunningham's Friday the Thirteenth (1980) establishing the slasher movie as a new genre, different in kind to that originating with Robert Bloch's and Alfred Hitchcock's Psycho (1962). These shifts remade the Gothic in an American image, but in so doing required the Gothic to discover new analogues for its original tropes.

American occult terrors lurked in the hidden corners of New York loft apartments and Brownstones and the homes of Washington diplomats and forests around small towns. This very American and almost nihilistic spirituality could not be combatted by anything other than the full weight of a revived Catholic Church, ready with exorcisms, holy water, prayer and candles. Such Catholicism, with its rituals, empty cavernous churches and warrior priests fighting the ancient evils inherent in the American condition, is, ironically, bereft of religious anchors and floating in a secular, consumerist hell-the American dream turned into nightmare. Catholic symbolism is now, however the rather lazy cliche of American gothic filmmakers of recent decades, entirely emptied of its original power and social meaning.

Other countries followed suit, their national concerns becoming a national modification of 'Anglophone' gothic imagery and language to their particular needs. In Italy the taste for gialli, a peculiar variation on the slasher movie, followed a decade in which British actors such as Christopher Lee were the stars of Hammer horror copycat movies featuring all the paraphernalia of an older nineteenth-century gothic world. These films, mostly made in black and white were eventually replaced by full colour renditions of a modern Italy rendered in fascist-modernist architecture that had little to do with the origins of the genre. Dario Argento's oevre is one based on a dreamlike and nightmarish twilight world where cinematography creates a peculiarly strange and alienated mise en scene inhabited by deranged black-gloved murderers who stalk victims in films in which there is a mixture of sex, violence, knives and extreme violence. In Profundo Rosso (1975) and Tenebre (1982), the slasher film takes on the qualities of type of hallucinatory surrealism peculiarly Italian in feeling and expression.

Films for the growing Spanish speaking audiences of America saw Browning's Dracula reshot at night and acted out for a Hispanic audience with Bela Lugosi replaced by Carlos Villarias and Browning giving way to George Melford. In Spain itself, during the 1970s older gothic stars such as Boris Karloff would make 
appearances in poorly made vampire flicks. Jesus (Jess) Franco also began making highly erotic versions of gothic classics in the 1970s alongside 'remakes' and reworkings of classic Dracula and Frankenstein themes. Female Vampire (1975) is one of a number of films which mixes horror and sex. In the film the vampire Irina Karstein (played by Lina Romay who is nude for almost every scene!) has taken to living in modern day Madeira and kills people by draining their vitality during sex. Such overt sexuality was unknown to British or American gothic films where any eroticism was heavily censored. In Franco's movies the Gothic is eroticised and violence replaced by sexual games.

Meanwhile, in Latin America during the 1980s the older European tropes, especially of vampires, were used to 'gothicise' contemporary social issues and as political critiques of dictatorial and exploitative regimes. The transition into transcultural 'Gothico Tropical' was first used in Luis Ospino's 'Pura Sangra' (1982) as a commentary on Colombian poverty, class division and uncaring dehumanised capitalism. ${ }^{3}$ In the first decades of the twenty-first century the work of Mexican director Guilermo del Toro has reinterpreted the Gothic through the lens of a fantastical rethinking of the 'repressed' history of fascism in Pan's Labyrinth (2006) and the romantic possibilities in the old Universal horror franchise with films such as The Shape of Water (2017), whilst the Spanish based tale The Nun (2018), directed by Corin Hardy returns to gothic literature's earliest tropes whilst referencing American films such as Daniel Meyrick and Eduardo Sanchez's The Blair Witch Project (1999) and Sean Gillespie's I Know What You Did Last Summer (1997) including, for good measure, a cast of millennial youngsters.

Whether in film or literature, television or interactive gaming, the Gothic becomes the space where secular fears reside and may be explored with the bonus of entertainment. Such space may only be relatively safe. As the Gothic grew through the last decades of the twentieth century the boundaries of the genre's taste and decorum, worked out through long practice, began to change. Stephen King was a relative conservative in reworking essentially 1950s gothicism, but he and James Herbert, although writing within the genre widened it to include scenes of abjection (Carrie [1974]) and disgust (The Rats [1974]). Both however were relatively conservative with references to Universal Films in Herbert's later books like The Magic Cottage (1988). King has a lasting obsession with a childhood in the 1950s. Herbert looks back to the ruins of the Blitz.

Clive Barker changed pulp horror, for he was interested in the sadistic and perverse within occult in suburban England. The creation of the Pinhead universe in The Hellbound Heart (1986) and the Hellraiser films was a Sadeian step into the pleasure of violence and the violence of pleasure. It coincided with the creation of the Torture Garden night club and the gender fluidity of sado-masochism. Sado-masochism pleasure combined with the frisson of fear was also to be found in Whitley Streiber's Communion (1987) a supposedly authentic story of alien abduction recalled through psychological therapy. Thus aliens, extreme sexuality and occult rituals were added to the gothic repertoire with the emphasis on body parts, bodily fluid (all shades of green and white and with the consistency of mucus), dismemberment and, above all blood, not the tomato blood 
of the Hammer horror films, but a new dark, viscous filmic blood which pools and spurts. Dark oozing or spurting blood, not 'red' splatter blood and beheadings seem the new symbol of trauma in gothic film.

The appearance of body gothic and torture porn has realigned Gothic with freakdom, but lost the earlier compassionate connection in tales such a Victor Hugo's moral tale The Man Who Laughs (1869) and the silent film version by Paul Leni, or even Browning's Freaks. Modern freakdom now combines weird science with zombification. Hence the Second World War may be 'gothicised' in ways that teeter on the brink of both racism and bad taste, but, nevertheless, stick closely to the gothic tropes of the dark forest and the subterranean dungeon and dark corridors of the eighteenth century. These are now metamorphosised into the atomic or experimental bunker, apparently abandoned but actually filled with the terrible detritus of a forgotten or repressed past - the past of an abandoned experimental hospital where plastic sheets and coils of electric wire suggest torture chambers and where the lights never work. Into this world the adventurers sally only to find blood-spattered walls and undead mutants. Such tropes are taken from the experiments of Josef Mengele and the horrors of Auschwitz. Most notorious of these films is Tom Six's The Human Centipede (2009) where the protagonists fall victim to a mad German dissectionist, but there is also the film series originated by Steve Barker in 2012 which pits a hapless group of soldiers against insane Nazi doctors and zombie stormtroopers, on which theme variations abound. In The Devil's Tomb (2009), directed by Jason Connery. Cuba Gooding Jnr leads a group of mercenaries into a labyrinthine tunnel to fight the Nephalim of the Book of Genesis.

Eli Roth seems intent upon reproducing horror from extreme nightmarish trauma. In this way he has dallied with film imagery that teeters upon torture pornography and the extremes of voyeuristic pleasure. His film Inferno (2013) is a version of the banned Italian film Cannibal Ferox (1981) directed by Umberto Lenzi which was itself a type of faux snuff movie about Brazillian cannibals and was banned in a number of countries. Such films seem to cross the line from being 'political' critiques of the destruction of the jungle by industrialisation to gruesome pastiches of the innocent American abroad caught up in the extreme violence of primitive savages. Each book or film picks up a number of tropes and wilfully or unknowingly reworks them for its contemporary audience and ecological gothic is an easy and contemporary way of making inexpensive movies with an environmental message. Whether it is a film set in mitteleuropeen backroads (Severance [2006] directed by Christopher Smith), Polish forests (Shrine [2010] directed by Jon Knautz), the depths of the Scottish Highlands such as Neil Marshall's werewolf adventure Dog Soldiers (2002), Irish bogs or English moors (Paddy Breathnack's 2002 remake of Shrooms or the Leprechaun series as well as Xmoor [2014] directed by Luke Hyams), each is a return to the exotic and orientalising modes of earlier iterations. Such reinterpretations often also reproduce the racist and xenophobic stereotyping they eschew.

Gothic literature has always been both tasteless and perverse as Samuel Taylor Coleridge pointed out in regard to his son's reading choices. Poe may be considered 'tasteless' in tales such as 'Berenice' (1835) or 'Ligeia' (1838) with 
their necrophilic and fetishistic endings. The decadence of horror movies such as the banned videos of the 1970s and 1980s (the 'video nasties' in Britain) or Six's Human Centipede II (2011) which provide very visceral entertainment may be more than an effect of corruption of taste due to the exhaustion of appetite. The notion of a decadent age suggests, not merely exhaustion, but nostalgia for a golden age, but what age is the golden age of gothic film and how is that to be judged and by what criterion? Gothic taste mutates.

Even at its origins the smell of sulphur and bad breeding stuck to works like those of Matthew Lewis, if not to Ann Radcliffe. Tastes change, but one cannot help but think that breaking good taste is partially what subversive gothic art is about and conservative gothic imagination tries to suppress. Hence two gothic worlds utilise the same imagery but for different purposes. The original tropes of the genre include moving from familiar and safer territory into foreign and therefore dangerous lands (mostly Italy, Spain and Germany, sometimes the East, and later, the Carpathian mountains in Transylvania), wicked aristocrats, castles, dark passages, dungeons and cellars, wild mountain landscapes and forests graveyards, bats and moonlight, lightening and thunder, threatened virgins, dark curses and dire warnings, occult practices and livid monsters or the undead which stalk battlement and chapel alike are still the tropes we have in contemporary versions of the genre which remain remarkably unchanged or are changed to mirror contemporary fears which are may not be too far away from their origins in the conservative version the genre. In Stanley Kubrick's 1980 reworking of Stephen King's The Shining (1977), an isolated and temporarily abandoned and 'haunted' hotel, complete with maze substitutes for a ruined castle; in James Wan's Saw (2004) it is an abandoned warehouse that substitutes.

Tropes are developed and attenuated, but stay true to a distant origin. Peter Blatty's nove, The Exorcist (1971), ground shifting turn into child possession and occultism, still began in the Middle East and a priest- archaeologist who uncovers ancient evil. Ridley Scott put the Gothic into space complete with fanged monster and dripping passageways in Alien (1979). Thomas Harris reinvented gothic literature with tales of an 'aristocratic' and monstrous psychopathic killer with six fingers and oubliettes full of victims, who is chased by a heroine of stoic proportion through museum crypts filled with deaths head moths; Dan Brown in The Da Vinci Code (2003) rethought part of the plot of the Matthew Lewis's The Monk with psychopath albinos and forbidden mysteries hidden deep in the Vatican.

Elsewhere, Eli Roth's Hostel (2005) reconstructs the dungeon as a touristic torture chamber in an abandoned facility in Slovakia, whilst in Hostel II (2007) he includes a scene clearly based on the supposed blood lust of the Countess Bathory and finishes with a pastiche of a Slovakian medieval folk festival. The black comedy, Severance (2009) directed by Christopher Smith, exchanges a Germanic Black Forest for a patch of forbidding nowhere in a former Soviet country (as does Brad Parker in The Chernobyl Diaries [2012]), whilst The Nun returns to eighteenth-century tropes regarding the Catholic Church. Indeed, in The Nun we have murder, revenge from a 'bloody and malevolent bloody nun', haunted seminaries, graveyards, thunderous skies, doubles and Catholic priests, most of the film 
centred on Spain as Dan Brown chose Italy. This is gothic nostalgia reworked as contemporary setting.

By the first decades of the twentieth century, the Gothic really needed no imagined historical setting to work in film, although allusion to the past was a prerequisite. Modernist Gothic is most evident in the Universal quickie, The Black Cat (1934) directed by Edgar G. Ulmer and starring Boris Karloff as Hjalmar Poelzig and Bela Lugosi as Dr. Vitus Verdigas, a mad architect and a revenge-filled doctor fight a strange psychological battle over a female American honeymooner, Joan Allison injured after a bus crash whilst in Hungary. The house that the architect Poelzig lives in is modernist deco dream, but it is built over a prisoner of war camp and fortress. In the old gun casements the architect stores dead women exhibited as fetishistic trophies. Everything in the house is contemporary but everything alludes to the past, the doctor returns as living 'revenant', the architect's wife (Karen played by Lucille Lund) moves as somnambulistically as a vampire and is dressed accordingly, the architect himself is an occultist with a hint of Aleister Crowley and he is finally flayed alive as the house/castle is blown to smithereens killing all inside except for the two honeymooners, typical American innocents abroad. As Verdigas remarks, in this high tech modernist edifice, 'even the phone is dead'.

The old tropes (now clichéd) are often updated as technology changes. Thus the strange environment of a laboratory and of modern technology replaced outdated equipment in Whales' version of Frankenstein, where the technology of the mad scientist's laboratory is no longer the vague suggestions of Mary Shelley's book, stranded in a time when such technological advances were impossible to describe. The electricity of Frankenstein's lab, Frankenstein's lab coat and the fact that his assistant Fritz stole the brain from a medical university's demonstration theatre constitute a modernity quite unlike the actual period of the original book's creation. Nevertheless, this is counterposed by the fact that the laboratory is in an abandoned tower (with no electrical connection), that Fritz is a hunchback cripple, and that the stolen brain is 'abnormal'. That the tower is constructed on German Expressionist lines, is at the centre of a horrific mountain storm and has a dungeon, more than compensates for the syringes, van der Graf generators, operating trolleys and surgical equipment, and the cinematic converter lamps that attempt to make the laboratory look 'modern'. Thus tradition is preserved in modernity.

So it is with later films where the banality of modern life is the natural setting for gothic fear, especially for those films set in the United States where suburban houses contain bathrooms (Hitchcock's Psycho) telephones (I Know What You Did Last Summer) and televisions (Poltergeist) and even toilets (The Nun) that harbour dark malevolence. Nowhere in an American kitchen is ever safe, the basement simply there to avoid. Suburbia contains horrors in ordinary objects as the Japanese film industry understood with Takashi Shimizu's The Grudge (2002 as $\mathrm{Ju}-\mathrm{On}$ and remade 2004) with its haunted lofts and hallways, Hideo Nakata's Ringu (1998) with the fear of video technology, Shin'ya Tsukamoto's Tetsuo the Iron Man (1989), with its erotic obsession with metal or Nbuhiko Obayashi's bizarre Hausu (1977). Nowhere has the Gothic been more successfully reinvented 
than in Japanese film of the last three decades with its images taken from folk fears, reproduced through the lens of filmic technique of the modern quotidian and mundane. Equally, platforms such as YouTube offer a smorgasbord of strange photographic images and backstories ever available for gothic appropriation. Even real 'murders' such as that of Elisa Lam (Lam Ho Yi) on 30 April 1991 at the Cecil Hotel in Los Angeles whose bizarre behaviour in a lift and corridor was caught on CCTV and appears even more disturbing than that of the corridor footage central to the weird goings-on in The Grudge may be appropriated. Lam's inexplicable death has spawned an industry of gothic explanations, conspiracy theories, accounts of serial killers and featured in films such as Dark Water (2005) and a number of television detective/horror stories. Thus art imitates life and life becomes a source of the macabre. Lifts in hotels have been a source of unease since the tsunami of blood which issued from closed elevator doors in The Shining. 'Found documentary footage' filmed on grainy handheld cameras, and first used in The Blair Witch Project now inform many low budget gothic horrors set in lonely or abandoned buildings. Yet, staples remain. Haunted asylums and silent hospitals still create a gothic frisson whether it be William Friedkin's The Exorcist III (1990), Martin Scorcese's Shutter Island (2010) or The House on Haunted Hill (William Castle 1959; William Malone 1999).

Despite a century of change the Gothic holds its own place in popular culture. Children as young as two or three regularly watched the Count von Count (a Bela Lugosi parody complete with purple skin, cloak and fangs) on Sesame Street and he now also appears on The Furchester Hotel, a Muppet show spin-off for very young children. Older children may watch Vampirina, a schoolgirl vampire based on Elvira's 1960s look, read the Goosebumps series by R. L. Stine or delve into Lemony Snicket. At the cinema there's the cartoon world of Hotel Transylvania, or films such as Scooby Doo for an older child audience. At the same time the Addams family came to the big screen in 1991 and 1993.

Dark vampiric heroes now haunt obsessional adolescent females in romance literature similar to that written by Ann Radcliffe at the end of the eighteenth century. Shelves are dedicated in bookshops to this subgenre, whilst in the late twentieth century there were television, film and book series such as Buffy the Vampire Slayer (1997-2003), True Blood (2008-2014) and Twilight (2008-2011). Young women may have more agency than in Radcliffe's day, but the tropes remain largely the same.

Wolfmen have been updated from their filmic origins in Stuart Walker's The Werewolf of London (1935) and George Waggner's The Wolfman (1941) to inhabit films like John Landis' An American Werewolf in London (1881) and Joe Dante's The Howling (1981), which references The Wolfman, but also were reimagined as a 'feminist' version of coming of age in movies such as in Ginger Snaps (2000).

More than any other film Ginger Snaps seemed the horror film for the millennium. Two EMO sisters of a loving but un-noticing suburban family are faced with harassment and school bullying as well as the onset of menstruation and sexual awareness. Adolescent female 'trauma' over periods (constantly referred to in the film as the 'curse' or the 'cramps' and graphically displayed in blood-red visuals 
which are both abject and terrifying), allows the narrative to take in both teenage angst and werewolf terrors; one sister growing a phallic tail, fur and fangs as sexuality dawns into animal lust, whilst the other 'plain' sister searches for a cure with her scientist boyfriend. The film ends as a type of old dark house slasher without closure or explanation. Yet if Ginger Snaps reinvents the Gothic for the teenager, so Drew Goddard's Cabin in the Woods (2011) is a film for horror aficionados. The film puts a very final line under the lost-in-the-woods gothic of old. Its comic apocalyptic message, put over by a group of victims clearly based on Scooby Doo's gang (with 'Shaggy' as the central character), makes it both a pastiche and a nihilistic critique of the manipulations of modern horror culture. Of course, it is $\mathrm{H}$. P. Lovecraft's dreaded 'Old Ones' who finally rise to create the apocalypse which in Lovecraft is always avoided.

As has been shown the Gothic does not stand still. Reworking old tropes and inventing new ways those tropes may be expressed is central to the gothic sensibility and new analogues follow as technology changes and society evolves. The old battlements and dungeons of the crumbling gothic castle may be rethought within contemporary spaces. Zombies now shamble across apocalyptic spaces and dead little girls descend backwards down the stairs of anonymous suburban houses. New twentieth-century monsters have emerged from the urban landscape too. Zombies and serial killers and urban scare figures taken from German fairy stories fill our films and the Internet. 'Victor Surge's' creation of the Slender Man in 2009 as a 'creepy pasta meme' was a modern rewriting of the Pied Piper tale emphasising the closeness of supernatural danger and childhood innocence in an age preoccupied with the fear of paedophiles and with the obsession of constant parent surveillance. Slender Man tells us the world has lost its innocence and danger is always in your peripheral vision.

The repertoire has widened too. The psychopathic clown has joined the repertoire of horror monsters. Almost always a deranged and deformed male, the clown has the same liminality as a vampire, an utterly ambiguous figure at once amusing and comforting and at the same time terrifying and monstrous, a mask of sheer malignity on his face and a grin hiding razor-sharp teeth. Moreover, the clown also belongs to the freaks and deformed protagonists who inhabit the horror circus of fear. It is in the circus that children first encounter clowns, who later return as the nightmares of adult memory, both something repressed and something half-forgotten, creatures who exist neither as reality nor simulacrum. Stephen King thinking about a new book and reminiscing about the Universal horror monsters recalled,

I had an idea ...that I wanted to write a really long book that had all of the monsters in it. I figured if people think I'm a horror writer... 'I'll get all of monsters together...; I'll get the Vampire, I'll get the Werewolf, and I'll even get the Mummy.... But then I thought to myself, There ought to be one binding, horrible, nasty, gross, creature kind of thing that you don't want to see, [and] it makes you scream just to see it. So I thought to myself, What scares children more than anything else in the world? And the answer was 'clowns'. So, I created Pennywise the Clown. ${ }^{4}$

The figure of the psychopathic clown is now ubiquitous, turning the 'infantalised' comfort of Ronald McDonald into psychopathic nightmare: the eater eaten. 
Clowns may be found in films such as Killier Clowns from Outer Space (1998), Spawn (1997), House of a Thousand Corpses (2003) directed by Rob Zombie, Zombieland (2009) directed by Ruben Fieschler, Stitches (2012) directed by Conor McMahon, as well as appearances in television programmes and series such as Stephen King's It from 1990 directed by Tony Lee Wallace (and revived for the screen in 2017 by Andy Muschietti) or American Horror Show, or as a masked rock musician in groups such as Slipnot). The clown is no longer portrayed as an innocent, slapstick comic in a circus with a red nose. Clowns are now figures of terror, malevolent freaks out to kill children, teenagers and party goers; even The Joker (dressed as Heath Ledger in Christopher Nolan's The Dark Knight [2008]) has taken on the motley and King's Pennywise and Zombie's Captain Spaulding have now joined the pantheon of memorable filmic horror characters.

The reappearance of the voodoo doll in the likes of Chucky (series beginning 1988) and the puppet in Saw (series beginning in 2009), as well as the maniacal laugh, pancake make-up and psychotic intent of the Halloween clown and living doll return us to the early gothic world of the circus freak, occult demon and the physically perfect automaton of European nightmares. With interactive augmented reality games such as Silent Hill Origins (2007), BioShock (2007), Gone Home (2013), Bloodborne (2015) and Night in the Woods (2017) and fairground thrill rides (with names like 'Vampire' at Alton Towers theme park) we can experience what once we could only imagine. The Gothic is the genre that describes itself, the genre of mutation continues to mutate into the twenty-first century.

Nevertheless, it is in the sphere of goth lifestyle, that mostly problematises the subject. Goths do not, in general, take an interest in gothic literature and may not even like horror movies. Their focus on bands, festivals and clubs which began in the 1980s is not directly tied to gothic history, but was (and remains) rather an independent reaction to dull working life. Gothic tropes inform gothic lifestyle but they have been modified for a new generation, now themselves middle aged. The emphasis on Victorian mourning wear and tight bodices for women and frilled shirts and heavy boots and leather coats for men with steampunk accessories for both genders as well as a considerable interest in Victorian imperial uniforms, cross-dressing and the affectations of Marie Antoinette suggest something quite different from the mainstream of Gothicism and even though the main gothic festival in England is held at Whitby with its associations with Dracula, a Dracula cosplay character is rarely encountered on the street during festival time. Even so, and despite the lack of interest in gothic literature, gothic lifestyle adheres to a tradition of gender fluidity, romanticism and masquerade inherent in gothic art from the nineteenth century, but dressed in an homage to the costumes from a Corman movie or a Hammer film by Terence Fisher. In this case the reproduction of Gothicism is a simulacrum of a simulacrum without origin or history, an experience of pure superficiality which nevertheless, wears a mask. Gothic lifestyle or cosplay amounts to the most serious form of carnival and cabaret where deception and seduction cloak a reticence regarding authenticity and where the authentic self is revealed only in the theatrics of serious play. Goths whose day time jobs may be mundane or tedious ironically become themselves or become their 'other' 
inherent or repressed selves in goth-inspired costume-revelation in disguised form.

Moreover how does one reconcile bands such as Siouxie and the Banshees, The Cure or The Sisters of Mercy who insisted, despite appearances, that they were not goths, or account for the work of illustrator Edward Gorey (perhaps the purist goth of all) whose Victorian cautionary tales he has referred to as surrealist rather than Gothic. Such conundrums complicate and confuse the issue of what exactly defines the gothic sensibility. ${ }^{5}$

This book is an exploration of the question: what has the Gothic become in the last hundred years? This volume contains seventy-two chapters covering the full range of gothic developments between 1918 and the present, written by the world's leading experts in the area. It forms the first volume of a series of three works which explore in the most acute and careful detail the development of the genre since its inception over 250 years ago.

\section{Notes}

1. A full study of the urban gothic of London by the editor will appear in the Palgrave Pivot series (2021).

2. The following are definitions from contributors to this volume and members of the International Gothic Association.

3. First brought to my attention by Leanna Talevera.

4. For the complete discussion see, https://www.thatericalper.com/2017/09/23/time-stephenking-met-pennywise-ronald-mcdonald/.

5. 'Hauntology' is perhaps the most obvious rethinking of the Gothic for twenty-first-century enthusiasts and appeared around 2003 to express interest in post-1960s popular culture. It not only includes filmic, televisual and online representations but is also interested in new age-ism, homoeopathic cures, occult and pagan ideas and the eerie. It is a culture of edge lands, and liminality, music and nostalgia and may ultimately be a very British phenomenon with the same roots as Edwardian ruralism.

\section{Bibliography}

Addams, Charles, Drawn and Quartered (London, Hamish Hamilton, 1943).

Addams, Charles, Homebodies (London, Hamish Hamilton, 1954).

Addams, Charles, Black Maria (New York, Simon Schuster, 1960).

Addams, Charles, Monster Rally (New York, Pocket Books Inc., 1965).

Addams, Charles, Favourite Haunts (London, WH Allen/Virgo Books, 1977).

Addams, Charles, The World of Charles Addams (Harmondsworth, Penguin, 1992).

Addams, Charles, The Addams Family Album (Harmondsworth, Penguin, 1992).

Anson, Jay, The Amityville Horror (London, Pan Books Ltd., 1983).

Austen, Jane, and Seth Grahame-Smith, Pride and Prejudice and Zombies (Philadelphia, Quirk Books, 2009).

Barker, Clive, Books of Blood: Volume Two (London, Sphere Books Limited, 1984).

Barker, Clive, Books of Blood: Volume Three (London, Sphere Books Limited, 1984). 
Barker, Clive, The Hellbound Heart (London, Fontana, 1991).

Bataille, Georges, Literature and Evil (London/New York, Marion Boyars, 1990).

Bloom, Clive, Gothic Histories: The Taste for Terror, 1764 to the Present (London, Continuum, 2010).

Bogdan, Robert, Freak Show: Presenting Human Oddities for Amusement and Profit (Chicago, University of Chicago Press, 1990).

Botting, Fred, Gothic (London, Routledge, 1995).

Brunvand, Jan Harold, The Vanishing Hitchhiker: Urban Legends and Their Meanings (London, Pan Books Ltd., 1981).

Burton, Tim, Tim Burton by Tim Burton (New York, Museum of Modern Art, 2009).

Cain, James, M., Double Indemnity (London, Pan Books Ltd., 1983).

Conrich, Ian, and Laura Sedgwick, Eds., Gothic Dissections in Film and Literature: The Body in Parts (London, Palgrave Macmillan, 2017).

Coolidge-Rask, Marie, London After Midnight (The Imaginary Book Company, [1928] 2012).

Davies, David Stuart, The Further Adventures of Sherlock Holmes: The Ripper Legacy (London, Titan Books Limited, 2016).

Davison, Carol Margaret, and Marie Mulvey-Roberts, Eds., Global Frankenstein (London, Palgrave, 2018).

Endore, Guy, The Werewolf of Paris (London, Panther, [1934] 1963).

Estleman, Loren D. Further Adventures of Sherlock Holmes: Dr Jekyll and Mr Holmes (London, Titan, 2010).

Estleman, Loren D. Sherlock Holmes vs. Dracula (London, Titan Books, 2012).

Forshaw, Barry, British Gothic Cinema (Basingstoke, Palgrave Macmillan, 2013).

Gorey, Edward, Amphigorey (New York, Penguin, 1972).

Gorey, Edward, Amphigorey Too (New York, Penguin, 1975).

Gorey, Edward, The Gashlycrumb Tinies (New York, Houghton Mifflin Harcourt, [1963] 1991).

Gorey, Edward, Amphigorey Also (New York, Penguin, 1993).

Gorey, Edward, Amphigorey Again (New York, Penguin, 2007).

Groom, Nick, The Vampire: A New History (New Haven, CT, Yale University Press, 2018).

Hanna, Edward B., The Further Adventures of Sherlock Holmes: The Whitechapel Horrors (London, Titan, 2010).

Haslam, Jason, and Joel Fafelak, Eds., American Gothic Culture (Edinburgh, Edinburgh University Press, 2017).

Herzogenrath, Bernd, The Films of Tod Browning (London, Blackdog Publishing, n.d.).

Hill, Susan, The Woman in Black (London, Mandarin Paperbacks, 1995).

Johnston, Derek, Haunted Seasons: Television Ghost Stories for Christmas and Horror for Halloween (Basingstoke, Palgrave Macmillan, 2015).

Jones, Darryl, Sleeping with the Lights On: The Unsettling Story of Horror (Oxford, Oxford University Press, 2018).

Kerr, Gordon, Cthulhu (London, Flametree Publishing, 2014).

Killeen, Jarlath, Gothic Literature 1825-1914 (Cardiff, University of Wales Press, 2009).

Lee, Vernon, The Virgin of the Seven Daggers (London, Penguin, 2008).

Leroux, Gaston, The Phantom of the Opera (New York, Carroll \& Graf Publishers, Inc., 1986).

Luckhurst, Roger, Zombies: A Cultural History (London, Reaktion Books, 2016).

MacArthur, Sian, Gothic Science Fiction: 1818 to the Present (Basingstoke, Palgrave Macmillan, 2015).

Manville, Roger, Masterworks of the German Cinema (London, Lorrimer Publishing, 1973).

McEvoy, Emma, Gothic Tourism (London, Palgrave, 2016).

Moore, Alan, Bolland Brian, and Higgins John, Batman: The Killing Joke (London, Titan Books Ltd., 1988).

Moore, Alan, and Eddie Campbell, From Hell (London, Knockabout Comics, 2006).

Morrison, Grant, Arkham Asylum (New York, DC Comics Inc., 1989).

Nelson, Victoria, The Secret Life of Puppets (Cambridge MA, Harvard, 2003).

Nelson, Victoria, Gothicka (Cambridge MA, Harvard University Press, 2012). 
Olson, Daniel, 21st Century Gothic (Lanham, MD, Scarecrow Press, 2010).

Piatti-Farnell, Lorna, Consuming Gothic: Food and Horror in Film (London, Palgrave Macmillan, 2017).

Piatti-Farnell, Lorna, and Maria Beville, Eds., The Gothic and the Everyday: Living Gothic (Basingstoke, Palgrave Macmillan, 2014).

Rice, Anne, Interview with the Vampire (London, Warner Books, 1996).

Roberts Chris, Livingstone Hywel, and Emma Baxter-Wright, Eds., Gothic: The Evolution of a Dark Sub Culture (London, Goodman, 2014).

Ross, Clifford, and Karen Wilkin, The World of Edward Gorey (New York, Harry N. Abrams, Inc., Publishers, 1996).

Round, Julia, Gothic in Comics and Graphic Novels (Jefferson, NC, McFarland \& Co., 2014).

Scharf, Natasha, Worldwide Gothic (Church Stretton, Shrops., Independent Music Press, 2011).

Skal, David, J. Hollywood Gothic: The Tangled Web of Dracula from Novel to Stage to Screen (London, Andre Deutsch, 1990).

Skal, David, J. The Monster Show: A Cultural History of Horror (London, Plexus, 1993).

Sonser, Anna, A Passion for Consumption: The Gothic Novel in America (Bowling Green, University of Wisconsin Press, 2001).

Strieber, Whitley, Communion: A True Story (New York, Avon Books, 1988).

Theroux, Alexander, The Strange Case of Edward Gorey (Seattle, Fantagraphics Books, 2000).

Thomson, Rosemarie Garland, Ed., Freakery: Cultural Spectacles of the Extraordinary Body (New York, New York University Press, 1996).

Wisker, Gina, Contemporary Women's Gothic Fiction (London, Palgrave, 2016).

Wolfreys, Julian, Haunted Selves, Haunting Places in English Literature and Culture, 1800Present (London, Palgrave, 2018).

Wood, Gabby, Living Dolls: A Magical History of the Quest for Mechanical Life (London, Faber and Faber, 2002).

Woolrich, Cornell, Black Alibi (New York, First Ballantine Books, 1982).

Woolrich, Cornell, Night Has a Thousand Eyes (New York, First Ballantine Books, 1983).

\section{Television}

Addams Family, The

Dr Who

Munsters, The

Penny Dreadful

Scooby Doo

Whitechapel

\section{Comics}

Haunt of Fear, The

Tales from the Crypt

Weird Science 


\section{Websites and YouTube}

Asian horror https://www.youtube.com/watch? $\mathrm{v}=\mathrm{MjjGBR} 18 \mathrm{n} 4 \mathrm{Y}$

Phantom https://www.youtube.com/watch?v=EExGWC0_OZA

http://www.gutenberg.net.au/ebooks06/0602571h.html

https://www.youtube.com/watch?v=T93x32Hkgj0

https://www.youtube.com/watch?v=4-4_dwFeLIo

https://www.youtube.com/watch?v=XfVj7RtsYxw

https://www.youtube.com/watch? $\mathrm{v}=$ suYKHimQwt4

https://www.youtube.com/watch?v=nzcyPweRyC8

https://www.youtube.com/watch?v=3gjrwV-XLRA

https://www.youtube.com/watch?v=Bi2tTPPUNL025.00

https://www.youtube.com/watch?v=WczgvZzoBL8

https://www.youtube.com/watch?v1.08=HWr_benB_QA

https://www.youtube.com/watch? $\mathrm{v}=\mathrm{gSk}-\mathrm{SGNBsS} 4$

https://www.youtube.com/watch?v=3fC3QzG_nGM

https://www.youtube.com/watch?v=wCUQg_j9yPw

https://www.youtube.com/watch?v=vS_fq9ii4Po

https://www.youtube.com/watch? $\mathrm{v}=\mathrm{hVqm1}$-rEttc

https://www.youtube.com/watch? $\mathrm{v}=\mathrm{oHA} 3$ wkltCns

https://www.youtube.com/watch?v=V7apuW_2lI

https://www.youtube.com/watch? $\mathrm{v}=3 \mathrm{VSb} 91 \mathrm{YO} 2 \mathrm{bw}$

https://www.youtube.com/watch?v=2rKHSpt02DM

https://www.youtube.com/watch?v=I2O7blSSzpI

https://www.creepypasta.com/

https://en.wikipedia.org/wiki/Slender_Man

https://www.youtube.com/watch?v=s_JK8uIywJM

https://www.youtube.com/watch? $\mathrm{v}=7 \mathrm{BChuMtWjYY}$

https://www.youtube.com/watch?v=LNKg8dvtqSQ

https://www.youtube.com/watch?v=IHKGoPSJsB4 